\title{
屈折版の模型実験に就いて
}

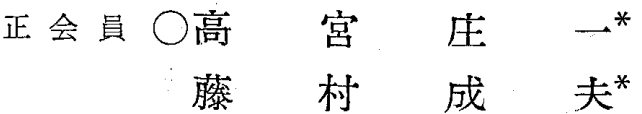

§1. 緒言 本試験は、試作住宅に実施すべく設計さ れた屈折屋根版の模型実験である。本架構を設計に採用 した要点は、1. 各平板は常時圧力が加わる状態にある ので亀裂が入り難い。2. 曲面板構法に比較して仮枠の 費用が掛らないと共に、コンクリート打が簡易であると の 2 つの理由に依る。

実験は異なつた配筋の 2 個の試験体を作成し、実験的 そ構造上の安全性を確めると共に、龟裂の発生より適当 なる配筋方法の検討、計算值と実験值の比較をなず゙く 実施したるのである。

§ 2. 試験体の形状、材料並びに作成 試験体任、実 施設計の四分の一の模型とした。各部寸法は第 1 図に示 す断面で桁間寸法は $1 \mathrm{~m} 707$ である。

試験体は、調合

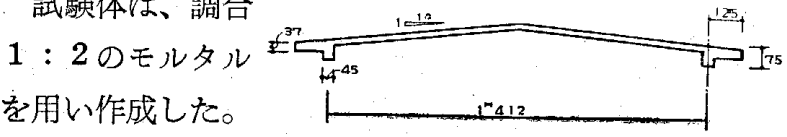

フローは 195 で 第1図 模型断面

セメントはアサノ早強セメント、砂は $1.2 \mathrm{~mm}$ 以下(豊 平川）のるのを使用、作成後は室内に試験時迄放置乙 た。試験体モルタル強度は第 1 表示す通りであり、A 試験体は、材令 14 19. 日で、B試験体材令 78 93 日で実験を行なつた。試験体の配筋は、ミ3、飞示す計 算方法にて応力を解析し、この結果をととして決定

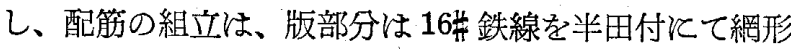
として使用し、梁部分は、な鉄線をも”つて結束し た。これら使用鉄線の引張試験結果は第 2 表々示す如く である。

§3. 構造計算 配筋決定に当つて、版部分は 4 辺固 第 1 表 供試体モルタル強度

\begin{tabular}{|c|c|c|c|c|}
\hline & \multicolumn{2}{|c|}{$\bar{A}$ 試 験 体 } & \multicolumn{2}{|c|}{$\overline{\mathrm{B}}$ 試 験 体 } \\
\hline & 4 週強度 & 試験時強度 & 4 週強度 & 試験時強度 \\
\hline $\begin{array}{c}\text { 曲げ応力度 } \\
\mathrm{kg} / \mathrm{cm}^{2}\end{array}$ & 55.0 & 19.7 & 51.8 & 51.6 \\
\hline $\begin{array}{c}\text { 压縮応力度 } \\
\mathrm{kg} / \mathrm{cm}^{2}\end{array}$ & 272.0 & 206.0 & 278.0 & 280.0 \\
\hline
\end{tabular}

第 2 表 鉄線引張試験

\begin{tabular}{c|c|c|c|c}
\hline & 供試何線 & 12 線 & 14 線 & 16 線 \\
\cline { 1 - 5 } 断面積 $\mathrm{cm}^{2}$ & 0.1288 & 0.0552 & 0.0314 & 0.0201 \\
\hline $\begin{array}{c}\text { 引張 強 度 } \\
\mathrm{kg} / \mathrm{cm}^{2}\end{array}$ & 5,993 & 7,249 & 7,223 & 8,960 \\
\hline
\end{tabular}

* 北海道立寒地建築研究所所員
定版とし算定をなし、裙梁炕ついては、第 2 図の如く梁 A B 間の 5 分点《入口 た補強筋、 $\mathrm{T}_{1}, \mathrm{~T}_{2}, \mathrm{~T}_{3}$ が裾梁の水

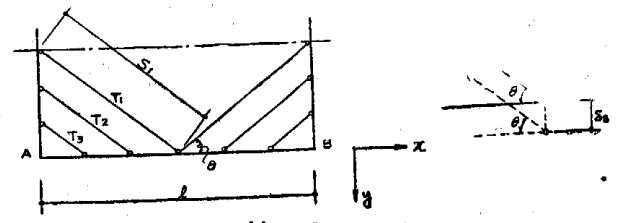

第“2 図

平方向の撓みに対して拘束を与光るものと仮定して、こ れらの点を支点とした連続梁として応力を算定する。

補強筋の伸び及び裾梁の撓み 補強筋が版よりの水平 力 $q$ を受けて伸びた後と和いてる、裙梁と補強筋との なす角 $\theta$ が変らないるのとすれば、補強筋 $\mathrm{T}_{1}, \mathrm{~T}_{2}, \mathrm{~T}_{3}$ ， の夫々の $y$ 方向の伸び $\delta_{s 1}, \delta_{s 2}, \delta_{s 3}$, は次の如くなる。

$$
\left.\begin{array}{l}
\delta_{s 1}=\frac{l}{2 \cos \theta \sin \theta} \cdot \frac{X_{1}}{A_{1} E_{s}} \\
\delta_{s 2}=\frac{l}{3 \cos \theta \sin \theta} \cdot \frac{X_{2}}{A_{2} E_{s}} \\
\delta_{s 3}=\frac{l}{6 \cos \theta \sin \theta} \cdot \frac{X_{3}}{A_{3} E_{s}}
\end{array}\right\}
$$

但し $X_{1} X_{2} X_{3}$ : 補強筋飞働く引張力 $(\mathrm{kg})$

$$
A_{1} A_{2} A_{3} \text { : 補強筋の断面積 }\left(\mathrm{cm}^{2}\right)
$$

第 3 図《於いて、裾 梁の軸方向力及び剪断 力の影響芓無視し、裾 梁の各点の撓 み $\delta_{c 1}$, $\delta_{c 2}, \delta_{c 3}$ を算出すれば、

(2) 式を得る。

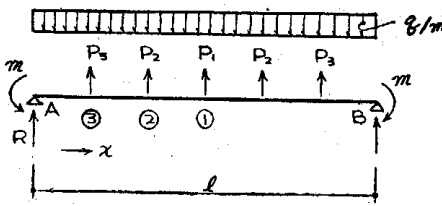
$\delta_{c 1}=l^{3}\left(6.75 P_{1}+10.0 P_{2}+3.5 P_{3}-3.385 q l\right) / 6^{4} E_{c} I$ $\delta_{c 2}=l^{3}\left(5.0 P_{1}+8.0 P_{2}+3.0 P_{3}-2.675 q l\right) / 6^{4} E_{c} I$ $\left.\delta_{c 3}=l^{3}\left(1.75 P_{1}+3.0 P_{2}+1.5 P_{3}-1.045 q l\right) / 6^{4} E_{c} I\right)$ 亦裾梁の雨端が鉸支持の場合の各点の蘑みは (3) 式とな る。

$$
\left.\begin{array}{l}
\delta_{c 1}=l^{3}\left(27 P_{1}+46 P_{2}+26 P_{3}-16.88 q l\right) / 6^{4} E_{c} I \\
\delta_{c 2}=l^{3}\left(23 P_{1}+40 P_{2}+23 P_{3}-14.68 q l\right) / 6^{4} E_{c} I \\
\delta_{c 3}=l^{3}\left(13 P_{1}+23 P_{2}+14 P_{3}-8.55 q l\right) / 6^{4} E_{c} I
\end{array}\right\}
$$

補強筋の引張力 裙梁の (1)、(2)、(3) 点に於ける梁の 撓及、 $\delta_{c 1}, \delta_{c 2}, \delta_{c 3}, \cdots$ 、補強筋の $y$ 方向の伸び $\delta_{s 1}, \delta_{s 2}$, $\delta_{s 3}$, 煌等しくなる。

$$
\delta_{c 1}=-\delta_{s 1}, \delta_{c 2}=-\delta_{s 2}, \delta_{c 3}=-\delta_{s 3}
$$

(4) 式江 (1) 式及び (2) 式を代入すると (5) 式を得る。

$$
\left.\begin{array}{l}
\left(6.75+n_{1}\right) P_{1}+10 P_{2}+3.5 P_{3}=3.385 q l \\
5.0 P_{1}+\left(8.0+n_{2}\right) P_{2}+3.0 P_{3}=2.675 q l \\
1.75 P_{1}+3.0 P_{2}+\left(1.5+n_{3}\right) P_{3}=1.045 q l
\end{array}\right\}
$$


但乙: $n_{1}=6^{4} E_{c} I / 4 \cos \theta \sin ^{2} \theta E_{s} l^{2} A_{1}$ $n_{2}=6^{4} E_{c} I / 3 \cos \theta \sin ^{2} \theta E_{s} l^{2} A_{2}$ $n_{3}=6^{4} E_{c} I / 6 \cos \theta \sin ^{2} \theta E_{s} l^{2} A_{3}$ 両端鉸支持の場合子前同様にて、(7) 式を求め得る

$\left(27+n_{1}\right) P_{1}+46 P_{2}+26 P_{3}=16.88 q l$

$23 P_{1}+\left(40+n_{2}\right) P_{2}+23 P_{3}=14.68 q l$

$13 P_{1}+23 P_{2}+\left(14+n_{3}\right) P_{3}=8.55 q l$

よつて、(5) 式、或は (7) 式を聯立に解いて $P_{1}, P_{2}, P_{3}$ を求めると、(8) 式より補強筋の引張力が夫々求めるこ とができる。

$X_{1}=P_{1} / 2 \sin \theta, X_{2}=P_{2} / \sin \theta, X_{3}=P_{3} / \sin \theta$,

裾梁の応力 裾梁部に加わる荷重は、この部分を固定

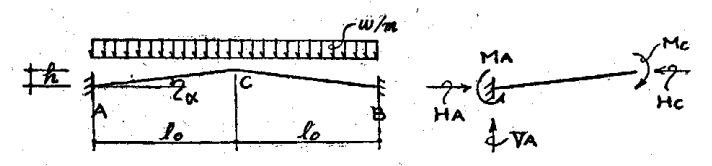

第 4 . 図

端として、版を第 4 図で 示す如き単位门の山形ラ ーメンとして、各荷重に 対して算定した。等分布 荷重に対する支点反力は

(9) 式となる。

$$
\left.\begin{array}{l}
M_{A}=M_{C}=w l_{0}{ }^{2} / 12 \\
V_{A}=w l_{0} \\
H_{A}=H_{C}=w l_{0}{ }^{2} / 2 h
\end{array}\right\}
$$

前項で算出した各式より、 この場合の裙梁の曲げモーメ

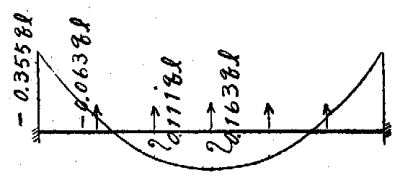

第 5 図
ントを求めると、第 5 図、及び第 6 図示す值となる。

これらの結果より、第 7 図及び第 8 図に示す 2 種の試 験体の配筋を決定した。

§4. 実験方法及測定装置 試験体は、ブロック壁体 上飞設置し実験を行なつた。等分布載荷試験は、1袋 $12.5 \mathrm{~kg}$ の砂鉄をつめた荷重を試験体の所定の位置に順 次第 9 図で見る如くに載荷した。破堙試験は亀裂の発生 状態を見る必要上集中荷重によつた。集中荷重は油圧

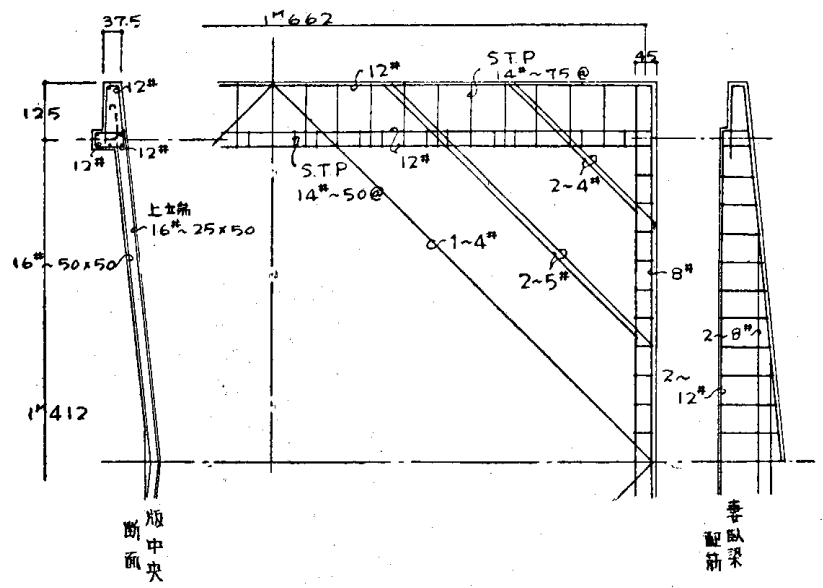

第 7 図、A 試験体

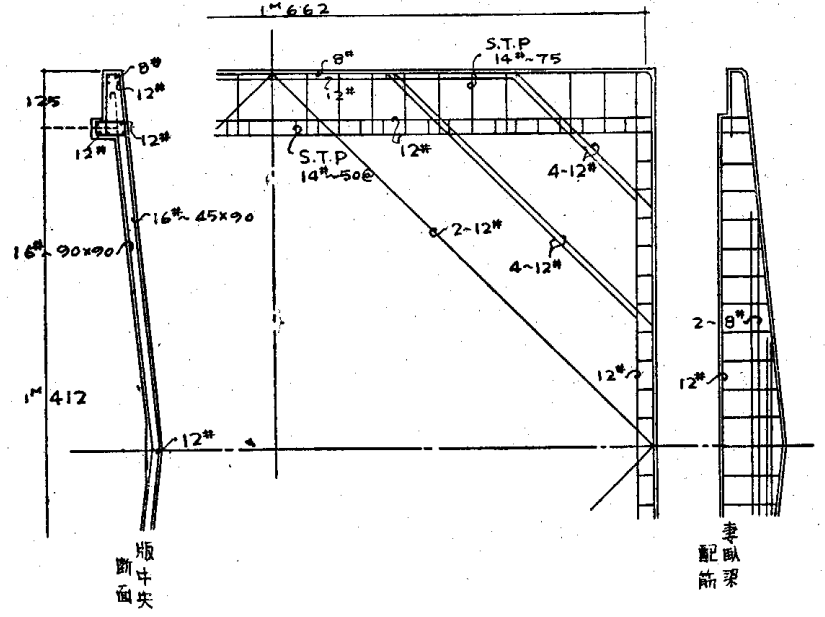

第 8 図 B 試験体

のシアッ
キーを用
い、武験
体との間
に力計を
入れ載荷
を行つ

た。A試

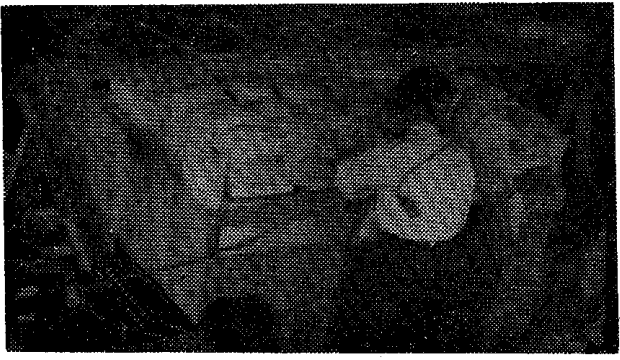

第 9 図

験体は、等分布荷重で $2,660 \mathrm{~kg}$ 汽 $\left(930 \mathrm{~kg} / \mathrm{m}^{2}\right)$ 載荷をし、 24時間放置した後荷重を除して集中荷重を加え、破壊試 験を行なつた。B試験については、等分布荷重の繰返し 試験を行なつた。荷重は、430 kg/m²（全荷重 $1.225 \mathrm{~kg}$ ) と、645 kg/m² (全荷重 $1,837.5 \mathrm{~kg}$ ) の2 種依つて垁験 した後、A試験体同様集中荷重に依つて破壞実験を行な つた。この間、歪 の测定は、S M 型抵抗線歪测定

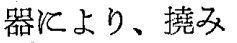
を $1 / 100 \mathrm{~mm} \mathrm{の}$ ダイヤルゲーヂ 浅て测定を行つ た。第 10 図は 昰及び撓み測定 位置を示す。

$\S 5$. 測定結 果 等分布荷重 に対する変位の

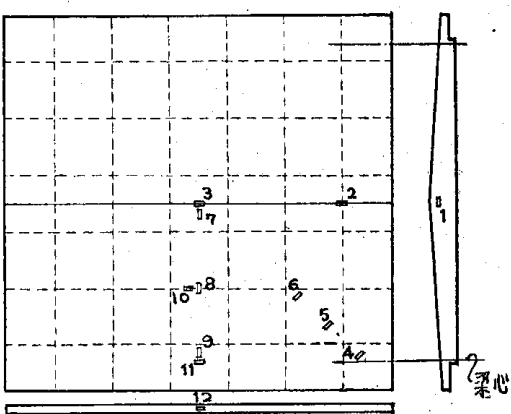

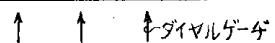
$\mathrm{Na} 3$ No2 Nol
测定結果は、第 11 図、第 12 図、第 13 図に示す。

$\mathrm{A}$ 試験体の撓み曲線は載荷重 $430 \mathrm{~kg} / \mathrm{m}^{3}$ (全荷重 $1,225 \mathrm{~kg}$ ）迄は注淔線的汇変化している。その変化は 版中央の垂直方向で $0.5 \mathrm{~W} \times 10^{-4}$ にて表わされる直線保 類似し、裙梁市央の水平方问での撓みは、0.5 W $\times 10^{-5}$ そて表わされる直線に類似した撓み曲線を示している。 即ち裾梁中央の水平方向の撓みは、版中央のそれの、 


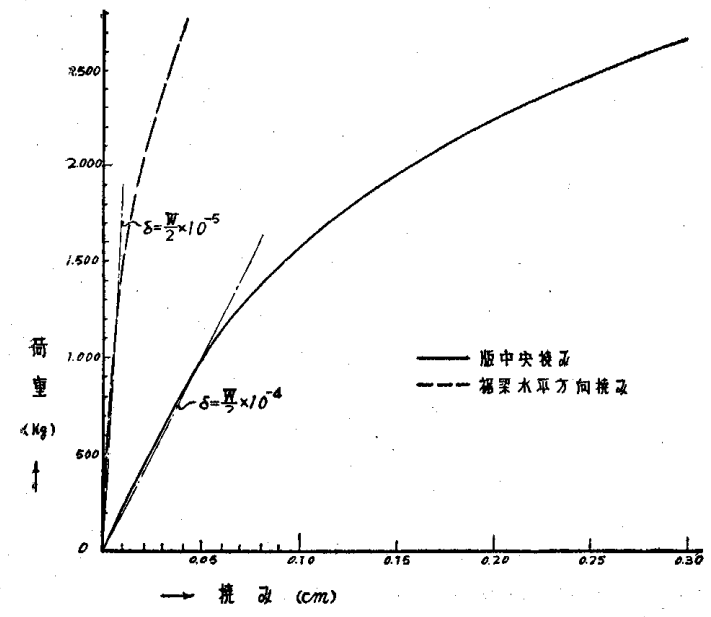

第 11 図

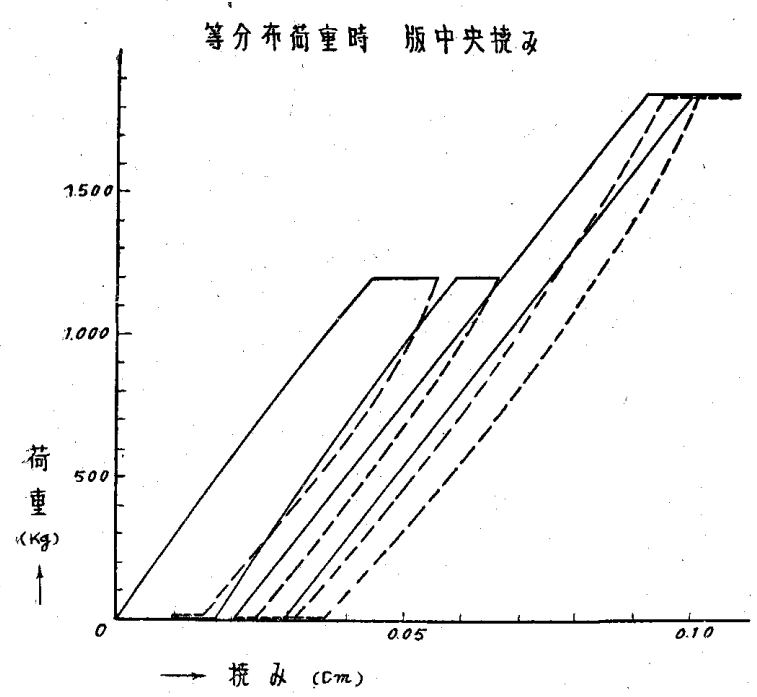

第 12 図等分布荷重時版中央撓み

1/10 の值の変形をしているととてなる。B試験体の繰 返し荷重による版中央の撓みは、いずれの繰返し荷重の 場合でもほぼ直線的変化を示し、それは $0.4 \mathrm{~W} \times 10^{-4}$ で表わされるようであ

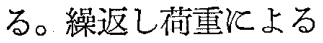
残留撓みは、いずれの 場合子 $0.1 \mathrm{~mm}$ 程度 の值である。

裙梁の撓みを、各荷 重時について表わすと 第 13 図の如くなる。

集中荷重による版中 央垂直方向の撓みの測 定結果は、第 14 図、 第 15 図々示す。第 14 困は繰返乙荷重時の測 定值である。その撓み 裙梁の搷正曲智

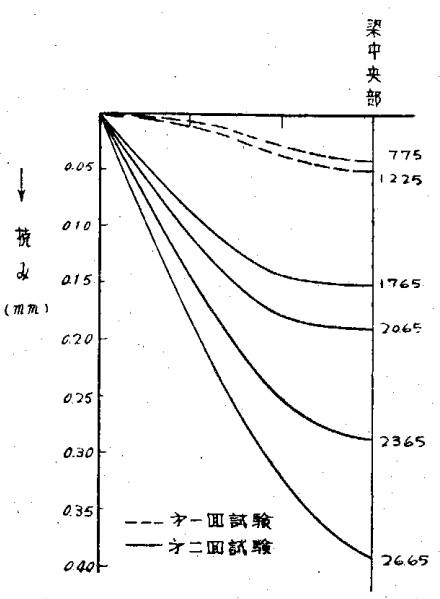

第 13 図裙梁の撓み曲線 值をみるに、等分布荷重時より大きい撓及值を示してい
るとす拘わ

らず、残留

撓みが零に

等しいのは 荷重載荷 後、その放 置をせず直 ちに荷重を 除去したこ

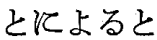
考えられ る。

第 15 図 はB試験体

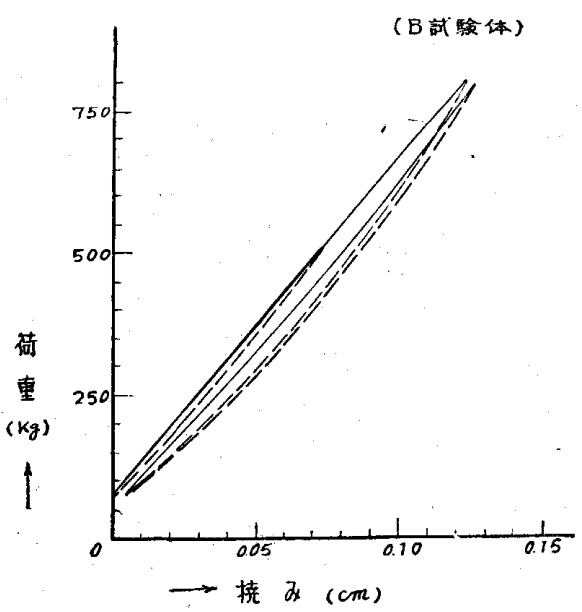

第 14 図集中荷重時版中央暁及 (B試験体)
の破壊実験と和ける版中央垂直方向の撓みである。この 場合子荷重が 1 ton 迄は前同様な直線的変，化で撓み、 1.15 ton で亀裂が発生その後は荷;重の増大なくても、 撓みは増加し破壊機構に至る。

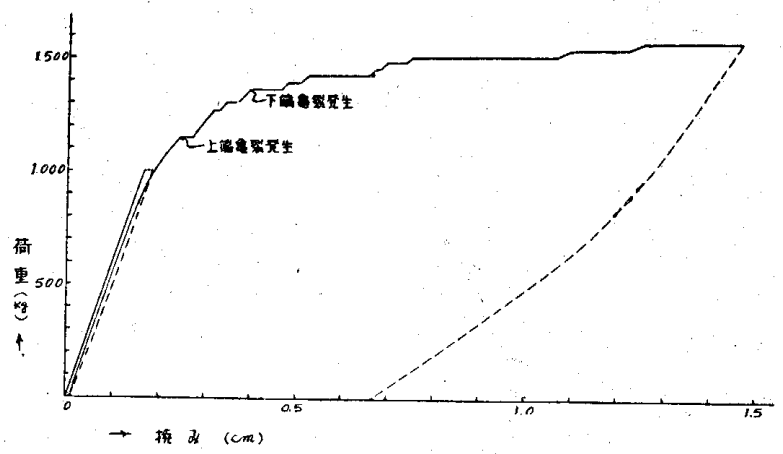

第 15 図集中荷重飞よる版中央撓み（B試験体）

86. 亀裂並びに破壊状況，試験体の破壊は、龟裂発 生状況を観察する必要上、版中央部潗中荷重を加えて
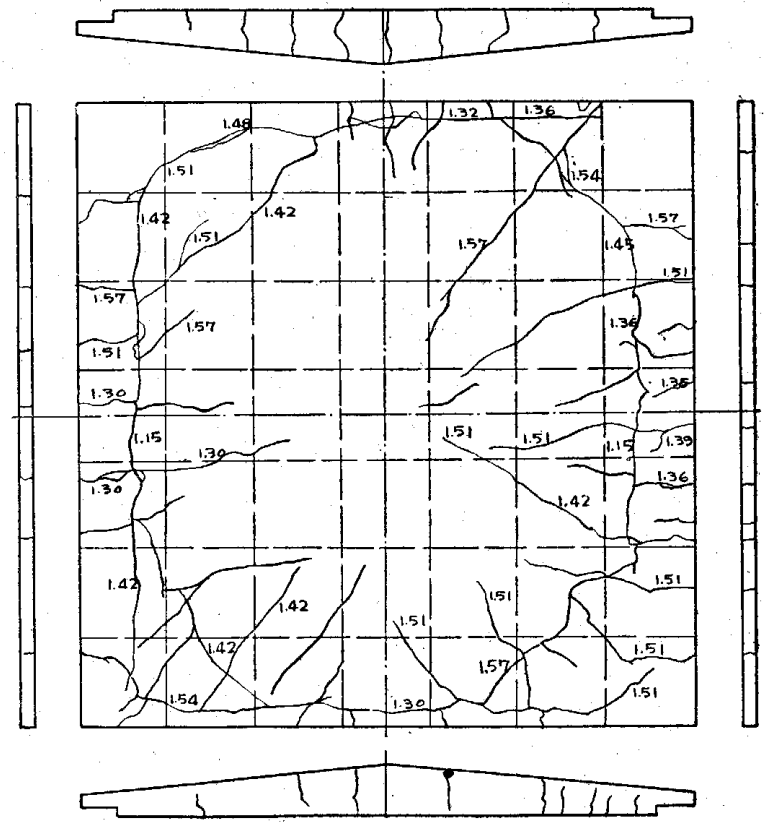

第 16 図 
行つた。
その亀裂
の上側の
状況を第
16 図に、
下側の状
況を第 17
図に示し
た。
最初の
亀裂は、
$W=1.15$
ton で裾

梁と版と

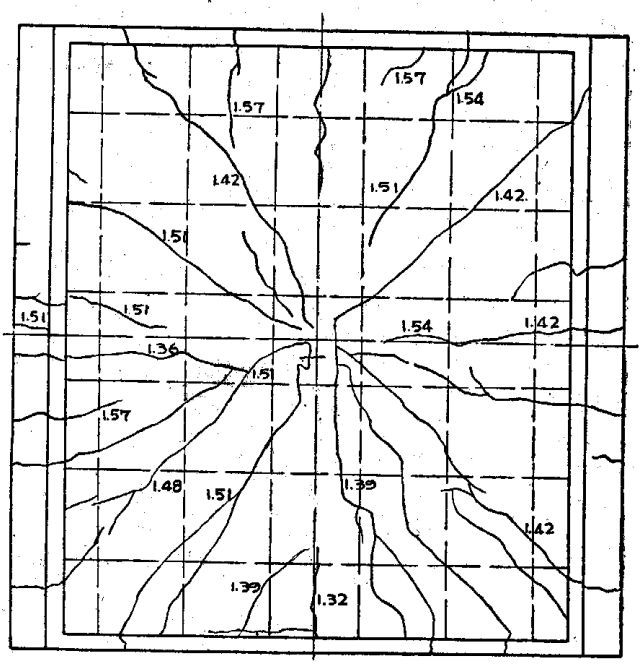

第 17 図

の境界ぞい反中央部に発生した。次いで $W=1.30$ ton で妻梁と版の境界ぞいに入つた。続いて $W=1.36$ ton で裾梁の中央部分上り梁間方向飞亀裂が入り、梁と版と の境界に入つた龟裂が、それぞれの梁スパンの 2 分の 1 程度になつた。下側の亀裂は、W=1.39 ton で入りそ の刍裂は、版隅部及び梁中央部分より荷重点飞向つて放 射状に入り始め、荷重の增加と共飞版中央点に達した。 荷重が 1.50 ton を過ぎると、版全体にわたり多数の亀 裂が発生し、1.57 ton では変形速度が加速度的飞増大 し始めたので、破壊状熊と判定し荷重を順次除去した。 この間の版中央の垂直方向の撓みは前項第 15 図に示さ れる如く、最大撓みは $14.7 \mathrm{~mm}$ で、荷重除去時の撓み は $6.7 \mathrm{~mm}$ であつた。

\section{§7. 実験結果に対する考察}

版の圧縮応力度 前項第 10 図の、8 点に括ける測定 值を第 18 図に示 す。

この歪度は、中立 面が版の中央にあ るるのと仮定し、 測定結果より算出 したのである。今 $\omega=423 \mathrm{~kg} / \mathrm{m}^{2}$ (全 荷重 $1,200 \mathrm{~kg}$ ) 時 の歪度を求める と、 $\varepsilon=-26 \times 10^{-6}$ となる。これより

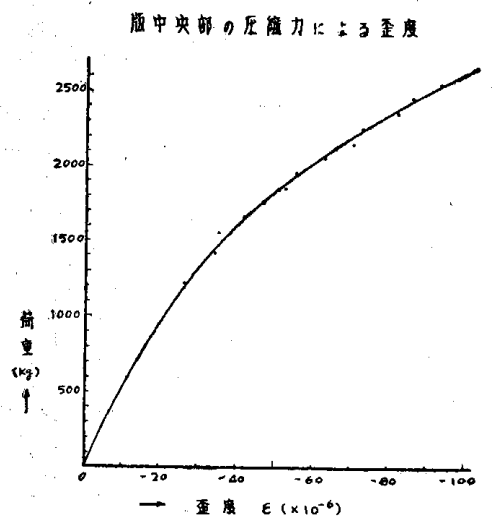

第 18 図版中央部の压緥力 による歪度
$E=2.1 \times 10^{5}$ 亿仮定し圧縮応力度 $\sigma$ を算出すれぼ次の値 となる。 $\sigma=-5.45 \mathrm{~kg} / \mathrm{cm}^{2}$

版中央 部の圧縮 力は、第 19図に示 す如き単 位巾を有

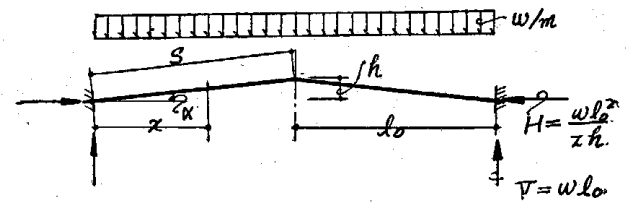

第 19 図
する届折梁として算定すると次の如き值となる。 $x$ 点の圧縮力

$$
N_{x}=w \cdot x \sin \alpha-H \cos \alpha-V \sin \alpha
$$

上式に各数値を代入 $x=l_{0} / 2$ 点の圧縮力を求めると、

$N \frac{l_{0}}{2}=3.55 \omega$ となり、圧縮応力度 $\sigma^{\prime}$ は次の如くな る。

$$
\sigma^{\prime}=-0.0142 \omega\left(\mathrm{kg} / \mathrm{cm}^{2}\right)
$$

(11）式より、 $\omega=423 \mathrm{~kg} / \mathrm{m}^{2}$ 時の压縮応力度を求める と、

$\sigma^{\prime}=-6.00 \mathrm{~kg} / \mathrm{cm}^{2}$ となり、前実験值との比は $\sigma / \sigma^{\prime}=$ 0.91 の値となる。

版中央部の曲げモーメント 前同様 の仮定以 基づき第 10 図 8 点の曲げ モーメン 卜を、歪 測定結果 より算定 すると第 20 図

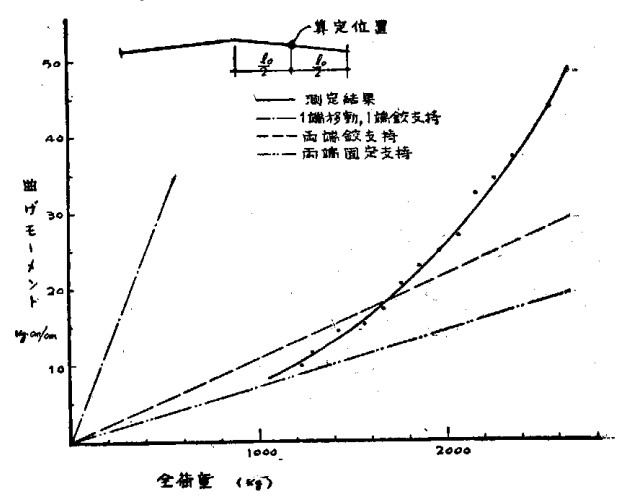

第 20 図版中央曲げモーメント 示す值となる。

これを考察するに設計荷重時では、裙梁の版に対する。 支持状態は、固定支持と鉸支持の中間と考克られる。

\$8. 結び 実験及び考察結果より、実施設計の構造 を検討すると充分安全であり、計算仮定もよく実験合 致しているようである。

稿を終るに当つて、種々御指導を賜つた熊本大学浅野一 教授厚く御礼申上げる次第である。 